\title{
Studies on optimum plant geometry and nutrient management strategy on biomass and economics of sugarcane (Saccharum species Hybrid)
}

\author{
Satendra Kumar*, S.P. Yadav ${ }^{1}$, Y.P. Bharti and B.L.Sharma ${ }^{1}$ \\ Genda Singh Sugarcane Breeding and Research Institute, Seorahi (U.P.) India \\ (Email : satendrayadav.agro@gmail.com)
}

\begin{abstract}
In a modern and sustainable agriculture, the use of biofertilizers, soil amendments and suitable plant geometry with mechanization are eligible to increase plant production and to meet economic criteria to enhance soil fertility and to minimize environmental damage. A field experiment for consecutive two years i.e. 2014-16 and 2015-17 was conducted at research farm of Genda Singh Sugarcane Breeding and Research Institute, Seorahi, Kushinagar in autumn season to find out optimum plant geometry and nutrients management for efficient use of machinery with economics. The soil of the experimental plot was medium in organic carbon, medium in available phosphorus and low in potash with $\mathrm{pH}$ 8.2. The experiment consisting of four plant geometry i.e. $\mathrm{S}_{1}-90 \mathrm{~cm}$ row spacing (conventional method), $\mathrm{S}_{2}$ - Trench planting in paired row at 120 (90:30) cm. $\mathrm{S}_{3}$ - Trench planting in paired row at $150(120: 30) \mathrm{cm} . \mathrm{S}_{4}$ - Trench planting in paired row at $180(150: 30) \mathrm{cm}$ and two nutrient management practices i.e. $\mathrm{F}_{1}-100 \%$ recommended dose of fertilizers through inorganics $\mathrm{F}_{2}-100 \%$ recommended dose of fertilizers through inorganics and $25 \% \mathrm{~N}$ through organic manures along with biofertilizers (Azotobacter + P.S.B. @ $10 \mathrm{~kg} / \mathrm{ha}$ each) was laid out in Factorial Randomized Block Design with three replications. On the basis of pooled data of two years, $\mathrm{S}_{2}$ treated plot produced significantly higher cane yield (104.72 t/ha) over other geometry operations. Gross income, net return (Rs. 175593/ha) and B: C ratios (1.50) were recorded significantly higher in $\mathrm{S}_{2}$ plant geometry treatment compared with remaining geometry treatments. Effect of nutrient management on gross return, net return, B: C ratio (1.44) and cane productivity (100.72 t/ha) were calculated significantly higher in $100 \%$ recommended dose of fertilizers through inorganics and $25 \% \mathrm{~N}$ through organic manures along with biofertilizers (Azotobacter + P.S.B. @ $10 \mathrm{~kg} / \mathrm{ha}$ treated plots $\left(\mathrm{F}_{2}\right)$ but effects on plant height and cane length were non significant. Sucrose per cent was not affected significantly with different treatments of plant geometry and nutrient managements operations.
\end{abstract}

Key Words : Sugarcane, Fertility, Biofertilizer, Biomass, Trench planting, Geometry, Economics

View Point Article : Kumar, Satendra, Yadav S.P., Bharti, Y.P. and Sharma, B.L. (2018). Studies on optimum plant geometry and nutrient management strategy on biomass and economics of sugarcane (Saccharum species Hybrid). Internat. J. agric. Sci., 14 (2) : $313-317$, DOI:10.15740/HAS/IJAS/14.2/313-317. Copyright@2018: Hind Agri-Horticultural Society.

Article History : Received : 20.04.2018; Revised : 21.04.2018; Accepted : 07.05.2018

\footnotetext{
* Author for correspondence:

${ }^{1}$ U.P. Council of Sugarcane Research, Shahajanpur (U.P.) India
} 